\title{
Macronutrient Omission Affects the Seedling Performance of Eugenia dysenterica DC., an Important Fruiting Species of the Cerrado Biome
}

\author{
Layara Alexandre Bessa ${ }^{1}$, Luciana Cristina Vitorino ${ }^{2} \&$ Fabianao Guimarães Silva ${ }^{1}$ \\ ${ }^{1}$ Mineral Nutrition and Plant Propagation Laboratory; Federal Institute Goiano, Rio Verde campus, Rio \\ Verde-GO, Brazil \\ ${ }^{2}$ Agricultural Microbiology Laboratory; Federal Institute Goiano, Rio Verde campus, Rio Verde-GO, Brazil \\ Correspondence: Luciana Cristina Vitorino, Federal Institute Goiano, Highway Sul Goiana, Km 01, Zona Rural, \\ postal code 75.901-970, Rio Verde-GO, Brazil. Tel: 55-64-3620-5600. E-mail: luciana.vitorino@ifgoiano.edu.br
}

Received: April 7, $2019 \quad$ Accepted: May 12, $2019 \quad$ Online Published: July 31, 2019

doi:10.5539/jas.v11n11p8 URL: https://doi.org/10.5539/jas.v11n11p8

\begin{abstract}
Cagaita (Eugenia dysenterica DC.) seedling production is currently important for the restoration of degraded areas of the Cerrado biome and to supply the demand for its fruits for regional food production. The plants of Cagaita have been described in the literature as resistant to nutrient-poor soils, but the studies remain inconclusive. Therefore, we tested the hypothesis that initial $E$. dysenterica seedling development could be affected by the lack of specific nutrients. We planted seedlings of this species in complete hydroponic solution and under individual macronutrient omission of $\mathrm{N}, \mathrm{P}, \mathrm{K}, \mathrm{Ca}, \mathrm{Mg}$ and $\mathrm{S}$. The development of macronutrient deficiency symptoms was visually monitored for 120 days after transplantation in response to the treatment solution, and growth characteristics and tissue contents of different macronutrients were determined. The omissions of $\mathrm{Mg}$ and $\mathrm{P}$ were the treatments with the strongest effects on seedling growth. The most commonly observed deficiency symptoms were chlorosis and necrosis, in addition to leaf purpling ( $\mathrm{P}$ deprivation), impaired root hair development ( $\mathrm{Ca}$ and $\mathrm{S}$ deprivation) and a reduced number of leaves ( $\mathrm{Mg}$ and $\mathrm{P}$ deprivation). The macronutrients $\mathrm{Ca}$ and $\mathrm{N}$ were most accumulated in the shoots and roots of plants subjected to complete nutrient solution, showing the importance of the availability of these nutrients in the initial stages of seedling development for the production of healthy Cagaita plants, with greater viability in the field.
\end{abstract}

Keywords: nutrient deprivation, hydroponics, growth, nutrient stress

\section{Introduction}

Eugenia dysenterica DC., commonly known as Cagaiteira, is a fruiting species that is native to the Cerrado and has potential for cultivation in traditional farming systems (e.g., Camilo et al., 2013). Interest in this species has been increasing due to its ornamental and economic value (Almeida, 1998). The latter is related to the direct use of its fruits as raw materials in the food industry (e.g., Santos et al., 2012) or of its wood to supply fence posts or cork. The chemical composition and nutritional value of the fruits, due to the levels of vitamins, minerals and phenolic and antioxidant compounds, have attracted the attention of researchers in the area (Sousa et al., 2018). Recently, polyphenols extracted from plants of the Myrtaceae family and specifically E. dysenterica were found to be effective in attenuating dyslipidaemia and inflammation (Donado-Pestana et al., 2018a; Donado-Pestana et al., 2018b). Because this plant is virtually widespread throughout the Cerrado, particularly in the central Cerrado region, its seedlings have been used in forest restoration programmes in this biome. Some studies have also demonstrated the medicinal potential of fruits (e.g., Moraes et al., 2008), latex (e.g., Marinho et al., 2011), leaf extracts (e.g., Silva et al., 2011) and juice essential oils of species of the Eugenia genus (e.g., Ogunwande et al., 2005; Santos et al., 2004).

Although there is a potential and growing market for fruits of regional interest, E. dysenterica remains underexploited, and its fruits are used only for extractive and predatory functions (Ribeiro et al., 2008). The impact on the population structure of this species throughout the Cerrado has been confirmed by genetic studies, which have indicated a reduced and geographic distribution-dependent gene flow (Telles et al., 2001; Zucchi et al., 2005). Therefore, the large-scale production and distribution of healthy $E$. dysenterica seedlings for the establishment of commercial farming areas play an important role not only in the generation of income but also in the implementation of conservation strategies, decreasing pressure on areas of natural occurrence of this 
species. Currently, however, limited knowledge on the nutrient requirements of $E$. dysenterica plants in the initial stages of their growth has hindered the production of seedlings of this species and, thus, their establishment in the field. Deficiency or excess problems are frequent due to nutrient application without scientific criteria (Resende et al., 2010).

Although Naves et al. (2002) have suggested that E. dysenterica plants show high adaptation to nutrient-poor soils, with high acidity, the presence of toxic aluminium and a large water deficit in some months, studies have shown that the type of soil on which the population grows may affect the tree phenotype (Telles et al., 2001) and that the occurrence of E. dysenterica in Cerrado areas may be strongly affected by the soil patterns (mineral occurrence) (Coelho et al., 2016). These studies indicate, therefore, that some nutrient limitations or even excesses may not be tolerated by E. dysenterica seedlings.

An understanding of the adequate macronutrient demand, especially during the critical seedling production phase, which is the initial development stage, is a fundamental step in this process (Munson, 2018) because it may guarantee the large-scale production of healthy seedlings with the potential to withstand adverse field conditions (Bessa et al., 2016). Nutrients affect plant growth because they work as the building blocks of organic matter, cofactors or signalling molecules (Coruzzi \& Bush, 2001). Thus, macronutrient deficiency or even toxicity promote metabolic disorders. A shortage of $\mathrm{K}$, for example, drastically reduces plant growth and productivity (Hafsi et al., 2014), whereas a lack of Mg affects the activity of several enzymes and the structural stabilisation of tissues (Guo et al., 2016). Conversely, a shortage of Mn directly affects the integrity of photosystem II (Schmidt et al., 2016). The metabolic problems generated by nutrient limitations, or even toxicity, manifest as symptoms, especially if the nutritional disorder is severe. These symptoms include reduced growth, leaf yellowing and/or purpling, necrosis or distorted growth of plant parts (Fernández-Escobar et al., 2016). Each mineral nutrient induces specific symptoms. Thus, visual symptoms help to identify nutritional disorders in plants. Visual diagnosis, however, may become rather complicated when more than one nutrient is deficient or when the deficiency of one nutrient is induced by the excess of another (Marschner, 2012). Therefore, a successful diagnosis also requires the analysis of plant anatomical and physiological traits and of data on growing and climatic conditions (Shear \& Faust, 1980). Thus, knowledge of symptoms, as a complementary tool in the diagnosis of deficiencies or toxicity, has great practical importance for the identification and rapid resolution of nutritional problems.

To test the hypothesis that the initial growth of E. dysenterica seedlings may be affected by the absence of specific macronutrients, we used the hydroponic method, which makes it possible to control the nutrients in nutrient solution, to test the effect of macronutrient omission of the growth and nutrient balance of these seedlings and to observe the visual symptoms triggered by these omission conditions.

\section{Materials and Methods}

\subsection{Seedling Production and Growth}

E. dysenterica fruits were collected from a natural population of this species located in a stretch of Cerrado sensu stricto at Gameleira Farm, municipality of Montes Claros, Goiás $\left(16^{\circ} 06^{\prime} 20^{\prime \prime} \mathrm{S}\right.$ and $51^{\circ} 17^{\prime} 11^{\prime \prime} \mathrm{W}$ at $592 \mathrm{~m}$ above sea level). Because the seeds of this species are typically recalcitrant (e.g., Silva et al., 2017b), they were removed from the fruits by manual pulping and immediately placed in plastic trays with autoclaved sand. At 30 days after sowing, the seedlings were transferred to the hydroponic cultivation system, planted in aerated plastic pots (8-L capacity) and kept in a greenhouse.

During the first 30 days in hydroponic solution, the seedlings were grown in Hoagland and Arnon (1950) nutrient solution at $1 / 2$ ionic strength of the treatment solutions. After this adaptation period, these solutions were replaced with the treatment solutions consisting of complete nutrient solution or nutrient solution with individual nutrient omission ( $\mathrm{N}, \mathrm{P}, \mathrm{K}, \mathrm{Ca}, \mathrm{Mg}$ and $\mathrm{S}$ ).

The solutions were prepared with deionised water, adjusting the $\mathrm{pH}$ to $5.5 \pm 0.5$, which was corrected daily with $\mathrm{HCl}$ and $\mathrm{NaOH}$ solutions. The solutions were always replaced when they reached $30 \%$ initial electrical conductivity.

The experimental design was completely randomised, and 06 macronutrient omission treatments and a control treatment, consisting of complete nutrient solution, were tested. Each treatment was assessed in four replicates, each represented by a pot with two seedlings, totalling 56 experimental units.

\subsection{Nutrient Deficiency Symptoms}

The plants were observed daily to detect visual symptoms of physiological disorders. The seedlings were periodically photographed to describe the appearance of macronutrient deficiency using a qualitative method. 


\subsection{Vegetative Growth and Macronutrient Content}

Growth was biometrically assessed at 30, 60, 90 and 120 days after transplanting (DAT) the seedlings in the hydroponic system. The study parameters were stem and root length, stem diameter and number of leaves. After the last study period, the plants were separated into root, stem and leaves and dried in a convection oven at $65^{\circ} \mathrm{C}$ to a constant weight to determine the dry matter weight.

After drying, the plants were ground in a Wiley mill with a 20 -mesh sieve to determine the root and shoot content of N, P, K, Ca, Mg and S, according to the method of Malavolta (1997).

\subsection{Statistical Analysis}

The calculated means of quantitative parameters were subjected to analysis of variance and the Tukey test at 5\% probability using the software environment R 3.4.4 (R Core Team, 2018).

\section{Results}

\subsection{Deficiency Symptoms and Macronutrient Content}

During all assessment stages, from 30 to 120 DAT, E. dysenterica plants grown in complete nutrient solution (with macronutrients) developed healthy leaves without symptoms of malnutrition. In these plants, the roots also developed normally, indicating effective nutrient uptake from the solution (Figure 1).

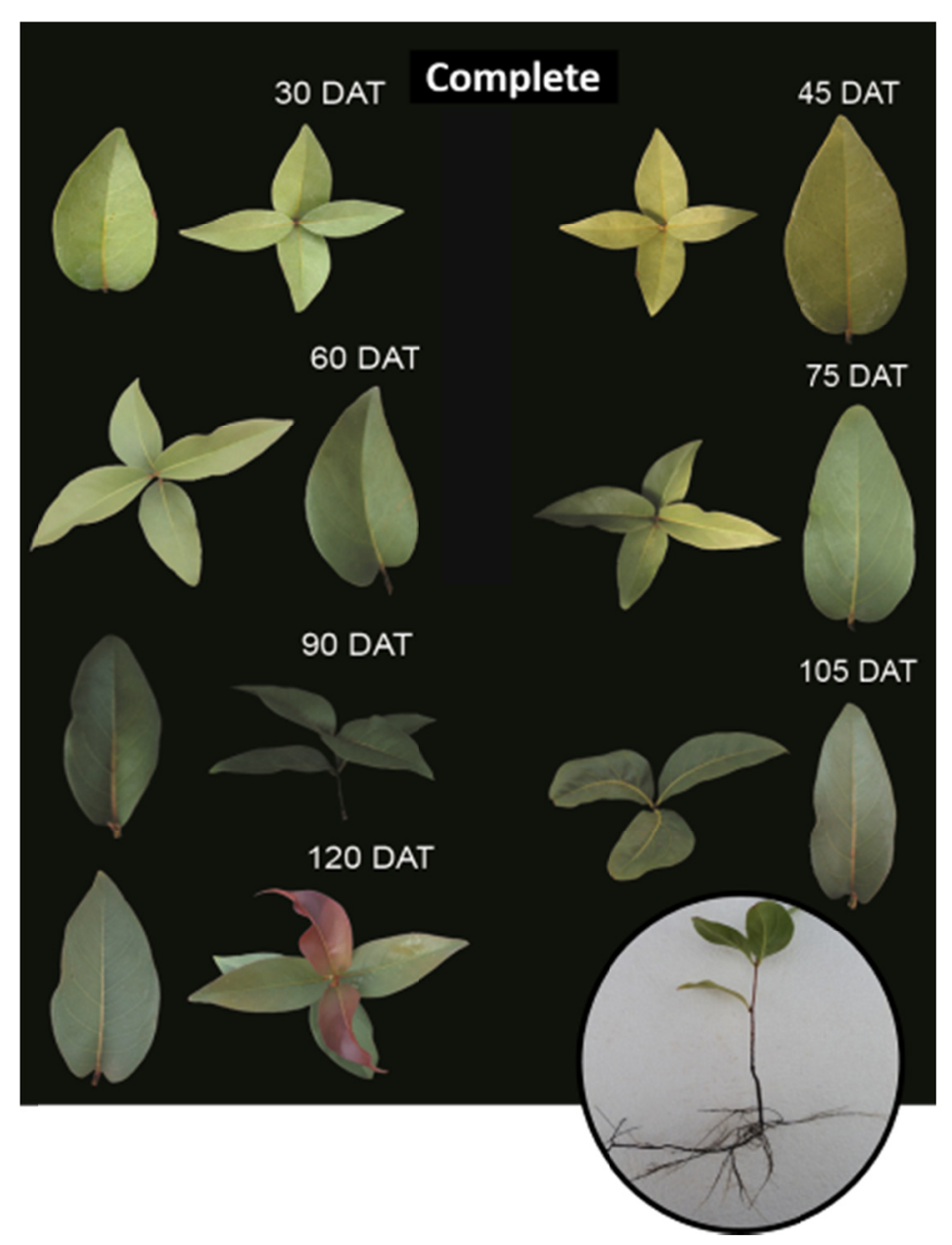

Figure 1. Visual appearance of leaves and shoots of Eugenia dysenterica DC. seedlings grown in a hydroponic system using complete nutrient solution (with $\mathrm{N}, \mathrm{P}, \mathrm{K}, \mathrm{Ca}, \mathrm{Mg}$ and $\mathrm{S}$ ). Records were acquired at 30, 45, 60, 75, 90, 105 and 120 days after transplantation (DAT) into the nutrient solution

Regarding symptoms of nutrient deficiency in plants subjected to macronutrient omission treatments, $\mathrm{N}$ deficiency symptoms were the first to appear (detected at 30 DAT). Widespread chlorosis was observed in the older leaves, progressing to initial necrosis detected at 45 DAT. At 75 DAT, chlorosis/necrosis became more 
frequent in plants and also occurred in younger leaves. Necrosis was always observed first in the leaf apex (region farthest from the petiole) and then spread to the blade. The roots, especially in the last two study periods (105 and 120 DAT), showed a high incidence of root hairs and reduced pigmentation (lighter tissues tending towards opacity) (Figure 2a).

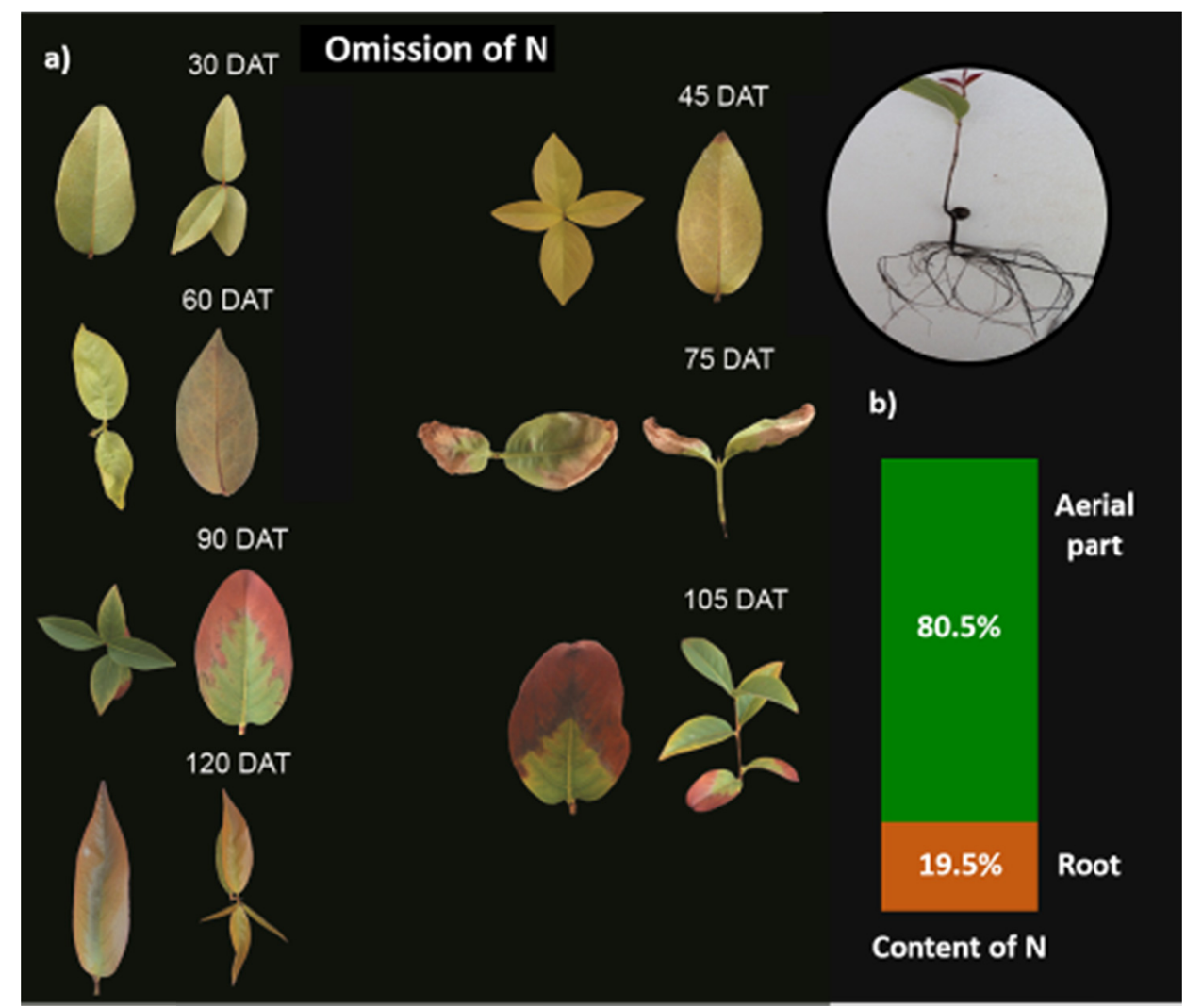

Figure 2. Visual aspect of N deficiency symptoms in leaves and shoots of Eugenia dysenterica DC. seedlings grown in a hydroponic system using nutrient solution without $\mathrm{N}$. Records were acquired at 30, 45, 60, 75, 90, 105 and 120 days after transplantation (DAT) into the nutrient solution (a). Shoot and root $\mathrm{N}$ partitioning of plants subjected to $\mathrm{N}$ omission (b)

Plants grown under $\mathrm{N}$ omission primarily accumulated $\mathrm{N}$ in shoots $(80.5 \%)$, and a small portion of this nutrient was allocated to roots (Figure 2b).

Ca deficiency in E. dysenterica roots was observed starting at 45 DAT with the onset of the first chlorotic spots (Figure 3a), although the leaf curling symptom was only detected in younger leaves starting at 75 DAT, followed by chlorosis and subsequent necrosis of these leaves. The roots showed the development of a long primary root, with few secondary roots. These roots were very dark, with no root hairs, especially starting at 60 DAT. Most of the $\mathrm{Ca}$ that accumulated in plant tissues was detected in shoots (65.3\%; Figure $3 b)$. 


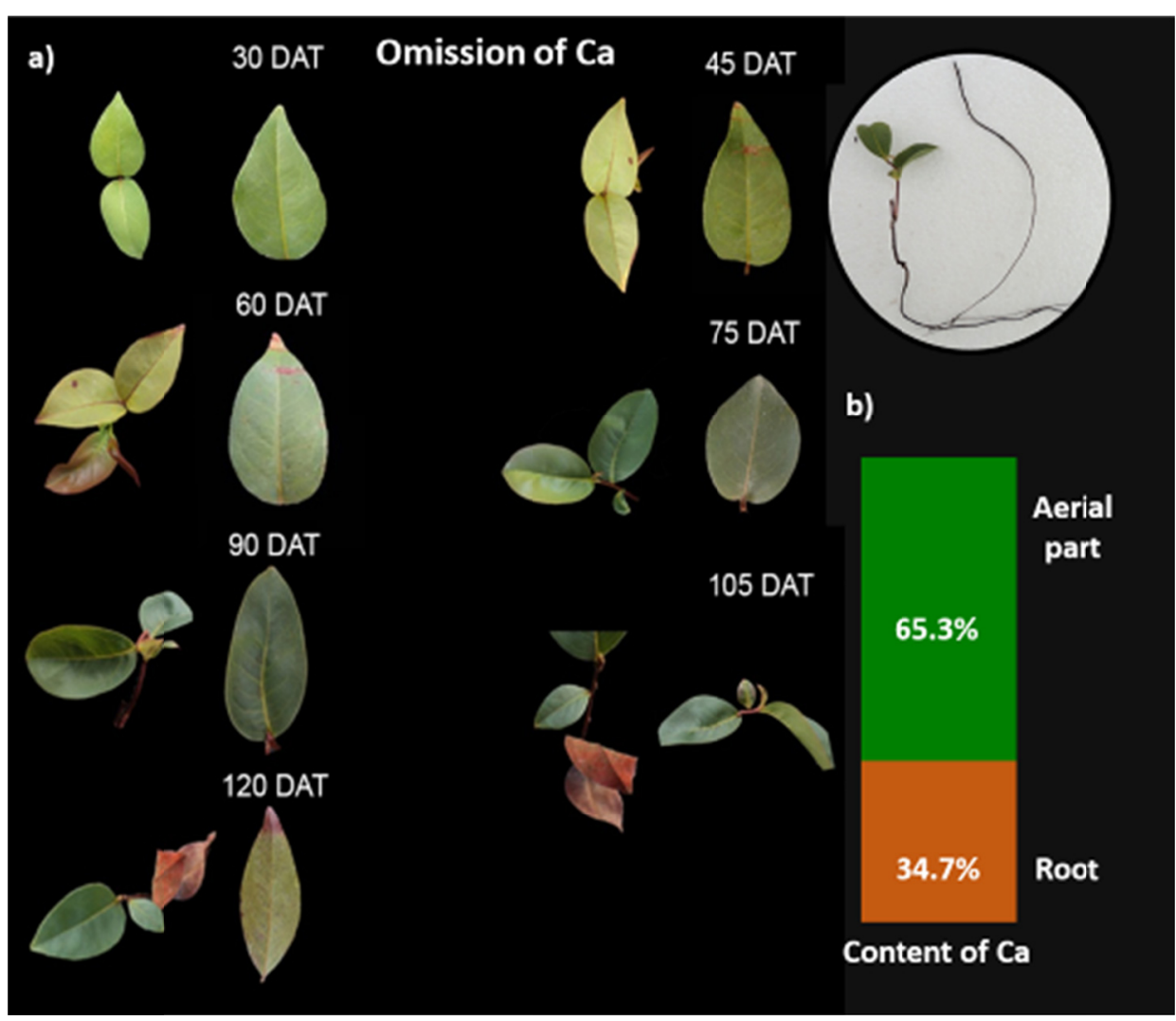

Figure 3. Visual aspect of Ca deficiency symptoms in leaves and shoots of Eugenia dysenterica DC. seedlings grown in a hydroponic system using nutrient solution without Ca. Records were acquired at 30, 45, 60, 75, 90, 105 and 120 days after transplantation (DAT) into nutrient solution (a). Shoot and root Ca partitioning of plants subjected to $\mathrm{Ca}$ omission (b)

Leaf symptoms of $\mathrm{K}$ deficiency were observed starting at 45 DAT. The seedlings developed necrotic spots throughout the blade, although the leaves developed yellowing symptoms only at 90 DAT, starting from the margin and progressing towards the midrib (Figure 4a). At 105 DAT, necrotic points became spots, and the roots were long, highly pigmented and had root hairs. Regarding $\mathrm{K}$ partitioning, $70 \%$ of this element was found in shoots (Figure 4b). 


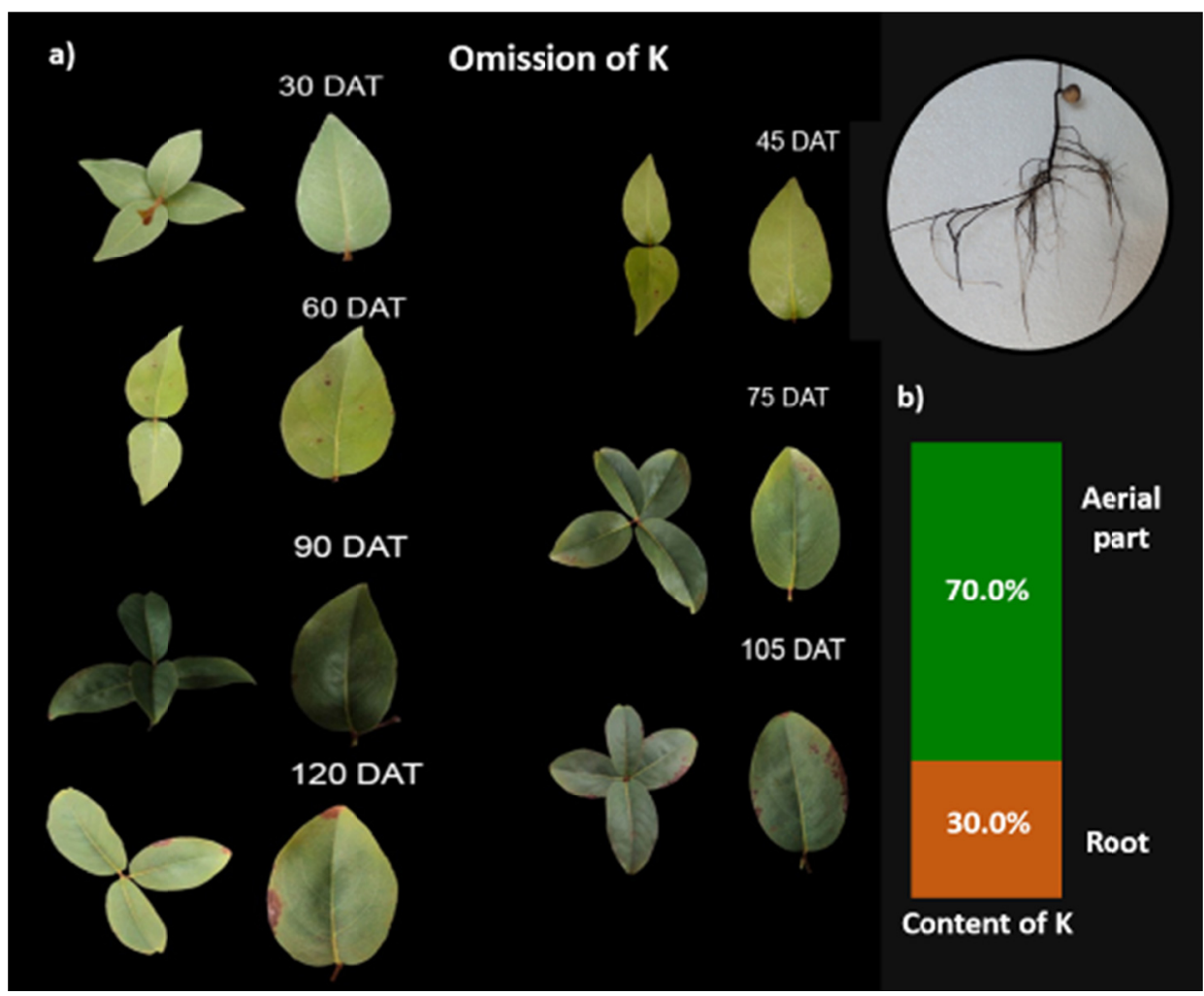

Figure 4. Visual aspect of K deficiency symptoms in leaves and shoots of Eugenia dysenterica DC. seedlings grown in a hydroponic system using nutrient solution without $\mathrm{K}$. Records were acquired at 30, 45, 60, 75, 90, 105 and 120 days after transplantation (DAT) into nutrient solution (a). Shoot and root K portioning of plants subjected to K omission (b)

Symptoms of P deficiency also became visible starting at 75 DAT when the older leaves developed purpling. This purpling was followed by leaf necrosis (Figure 5a). These plants also showed stunted stem growth with a reduced number of leaves and leaf nodes. Most tissue $\mathrm{P}$ was detected in roots $(81.4 \%)$, and only a small part was allocated to shoots (18.6\%; Figure 5b). 


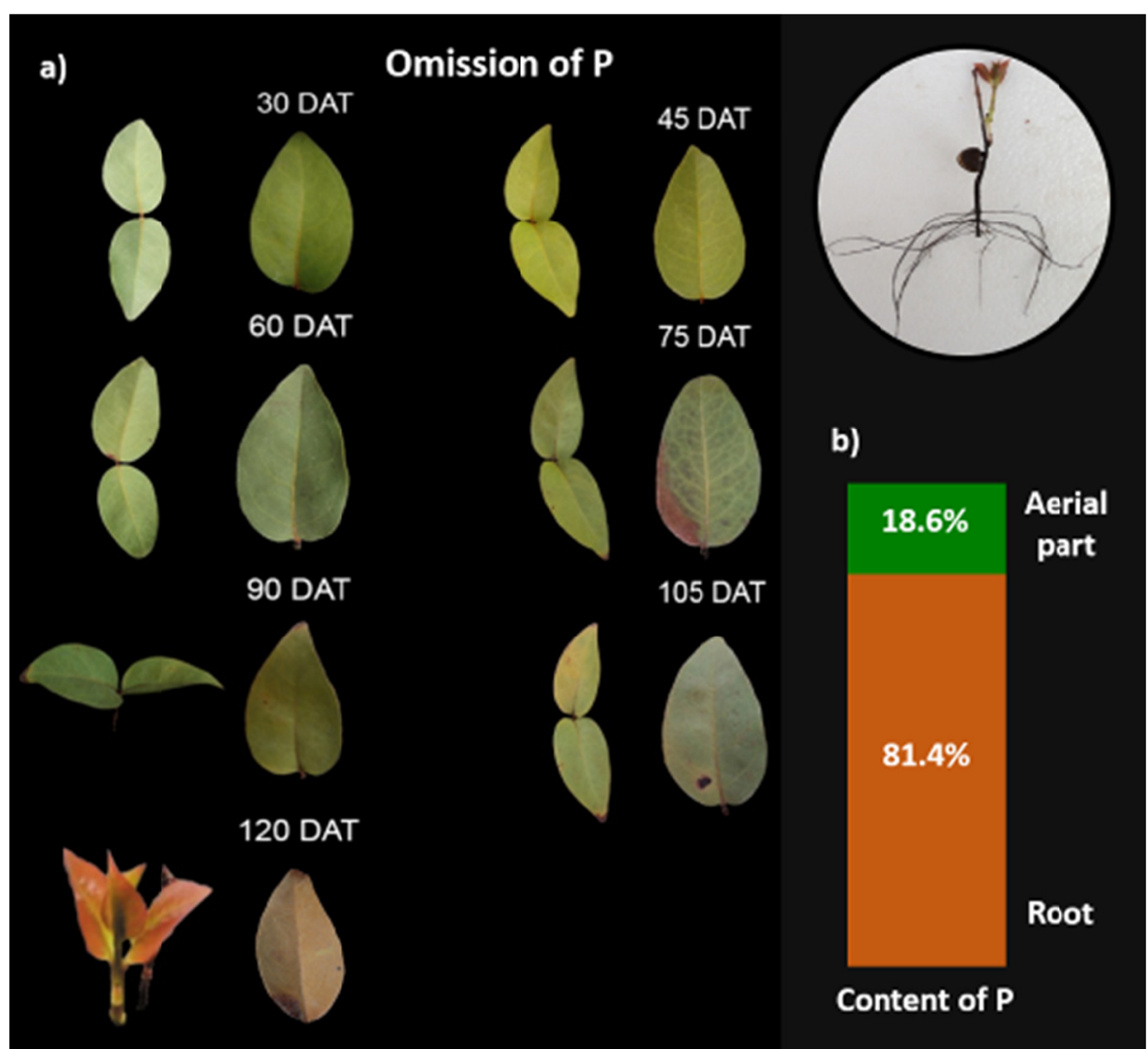

Figure 5. Visual aspect of P deficiency symptoms in leaves, shoots and roots of Eugenia dysenterica DC. seedlings grown in a hydroponic system using nutrient solution without $\mathrm{P}$. Records were acquired at 30, 45, 60, 75, 90, 105 and 120 days after transplantation (DAT) into nutrient solution (a). Shoot and root P partitioning of plants subjected to P omission (b)

Mg deficiency symptoms were detected at 75 DAT when the leaves showed widespread yellowing. Necrotic points were also detected throughout the blade. The leaves showed a pale appearance starting at 75 DAT and a marked decrease in plant growth with a reduced number of leaves and leaf nodes. The roots showed little branching with reduced secondary root development (Figure 6a). Most tissue Mg was found in the shoots of these plants (66.7\%; Figure 6b). 


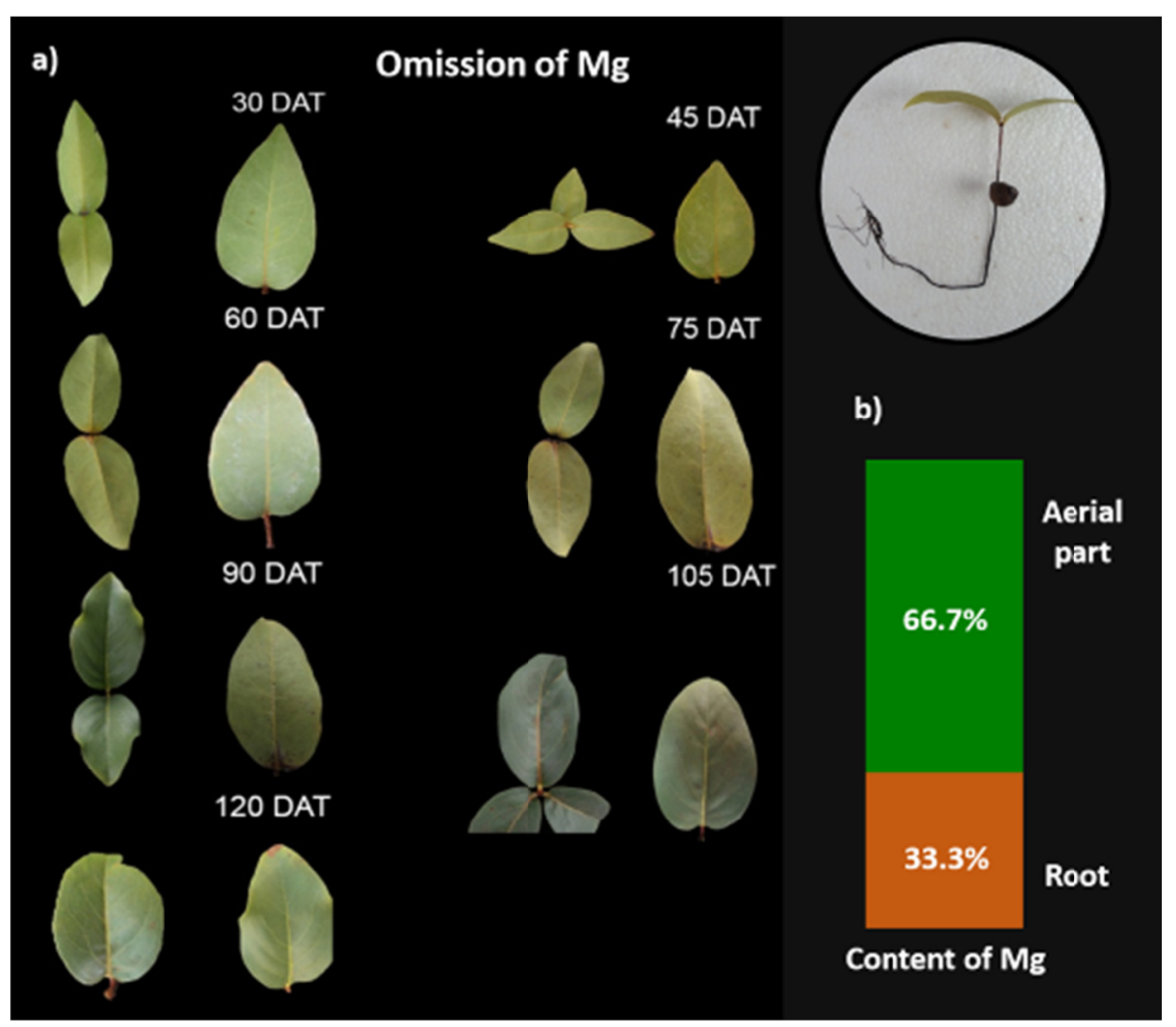

Figure 6. Visual aspect of Mg deficiency symptoms in leaves and shoots of Eugenia dysenterica DC. seedlings grown in a hydroponic system using nutrient solution without Mg. Records were acquired at 30, 45, 60, 75, 90, 105 and 120 days after transplantation (DAT) into nutrient solution (a). Shoot and root Mg partitioning of plants subjected to Mg omission (b)

A deficiency of S was detected in the initial period of exposure to omission (30 DAT), although necrosis was only observed starting at 105 DAT. The deficiency in this nutrient caused leaf fall and compromised the formation of secondary roots and root hairs (Figure 7a). Regarding the tissue partitioning of accumulated S, the highest percentage (71.4\%) was detected in the roots of plants subjected to the $\mathrm{S}$ omission treatment (Figure $7 \mathrm{~b}$ ). 


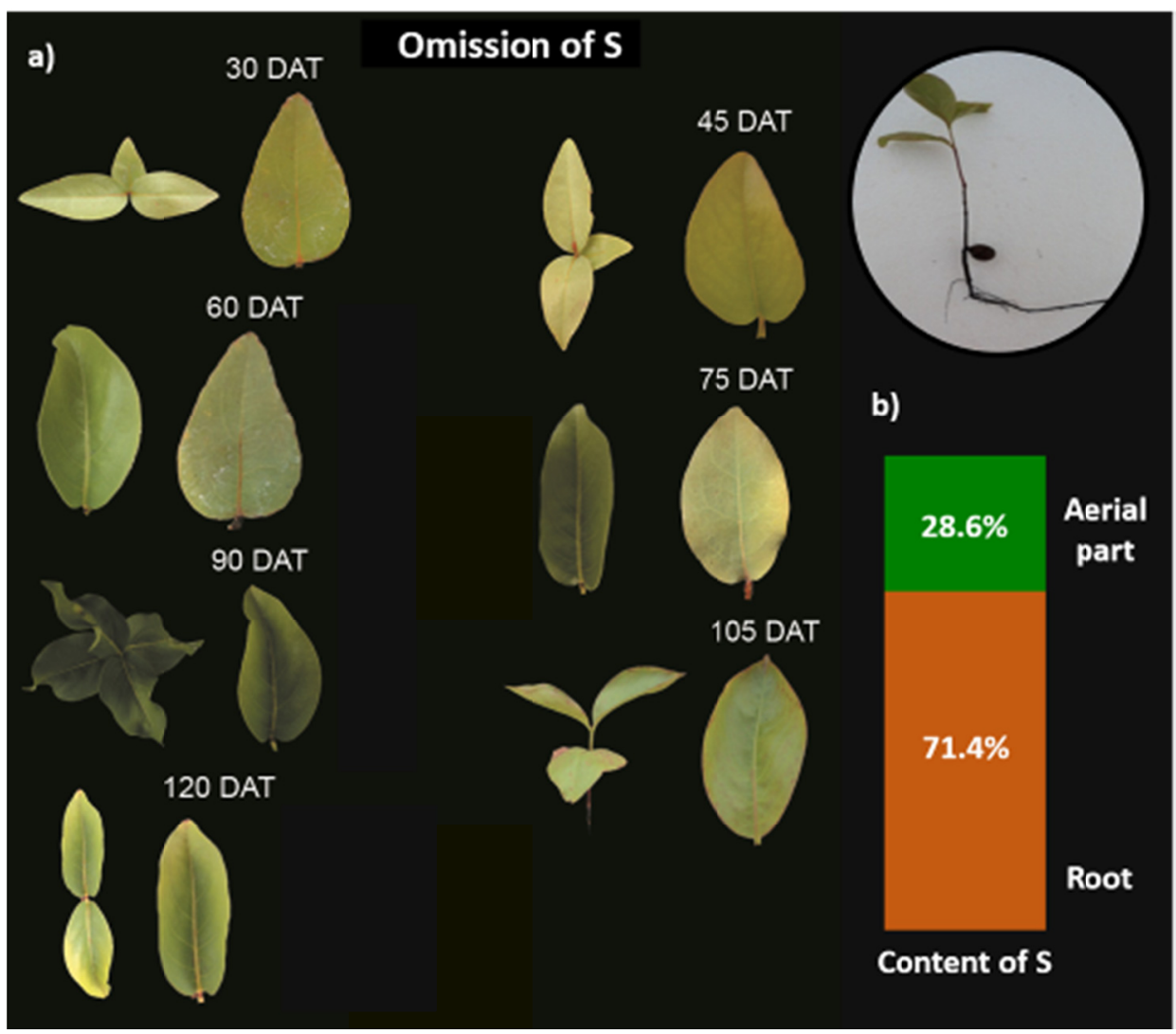

Figure 7. Visual aspect of S deficiency symptoms in leaves and shoots of Eugenia dysenterica DC. seedlings grown in a hydroponic system using nutrient solution without S. Records were acquired at 30, 45, 60, 75, 90, 105 and 120 days after transplantation (DAT) into nutrient solution (a). Shoot and root S partitioning of plants subjected to $\mathrm{S}$ omission (b)

The deficiency symptoms most commonly observed in E. dysenterica seedlings were chlorosis and necrosis (Figure 8). Each symptom was observed in plants subjected to the absence out of 06 nutrients tested. Only plants grown in the absence of $\mathrm{P}$ developed purple leaves, whereas the absence of $\mathrm{P}$ and $\mathrm{Mg}$ visibly affected the number of leaves. The development of root hairs was affected by the lack of $\mathrm{Ca}$ and $\mathrm{S}$.

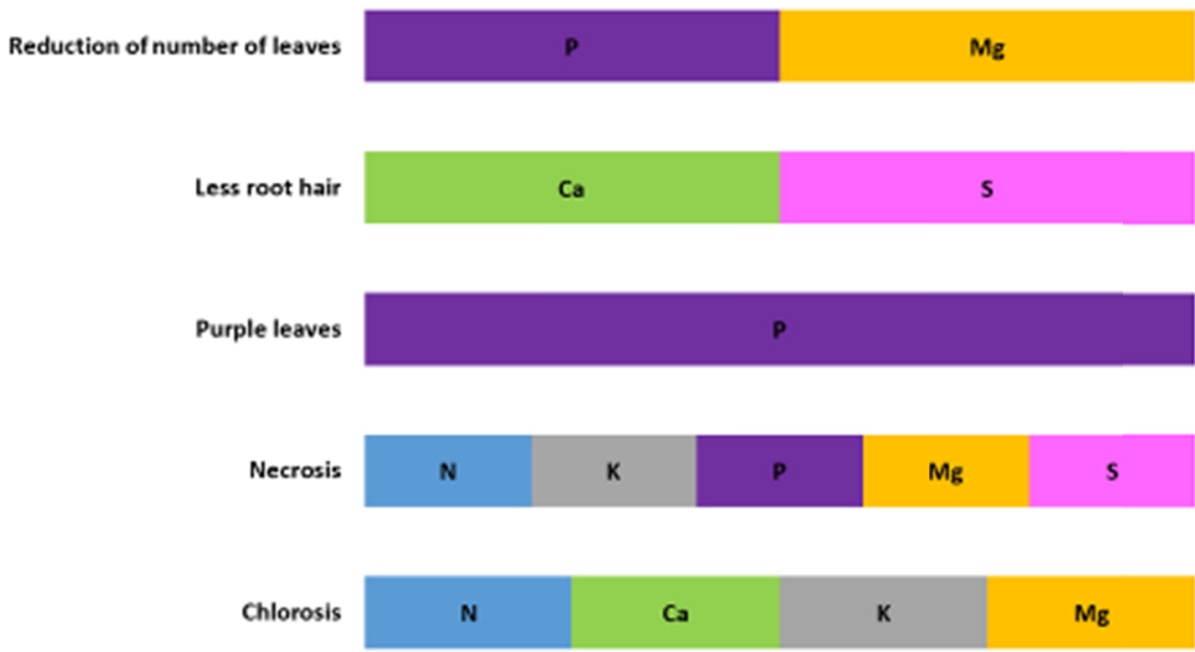

Figure 8. Main visual symptoms of nutritional deficiency observed in Eugenia dysenterica DC. seedlings grown in a hydroponic system using nutrient solution without $\mathrm{N}, \mathrm{P}, \mathrm{K}, \mathrm{Ca}, \mathrm{Mg}$ and $\mathrm{S}$. The tables outline the nutrient omission treatment in which the aforementioned symptoms were assessed during seedling development 


\subsection{Vegetative Growth}

Throughout the production cycle of E. dysenterica seedlings, $\mathrm{Mg}$ and $\mathrm{P}$ omission treatments had the strongest effects on stem development, showing the lowest mean stem lengths at 120 DAT (4.63 and $4.47 \mathrm{~cm}$, respectively). Conversely, the mean stem length observed in response to treatment with complete nutrient solution was $6.86 \mathrm{~cm}$ (Figure 9a). Unexpectedly, $\mathrm{N}$ omission had no apparent effect on stem growth, and the mean stem length in this treatment $(7.16 \mathrm{~cm})$ was even higher than that observed in the treatment with complete nutrient solution, albeit with a large variation in stem length values, ranging from $3.8 \mathrm{~cm}$ to $11 \mathrm{~cm}$.
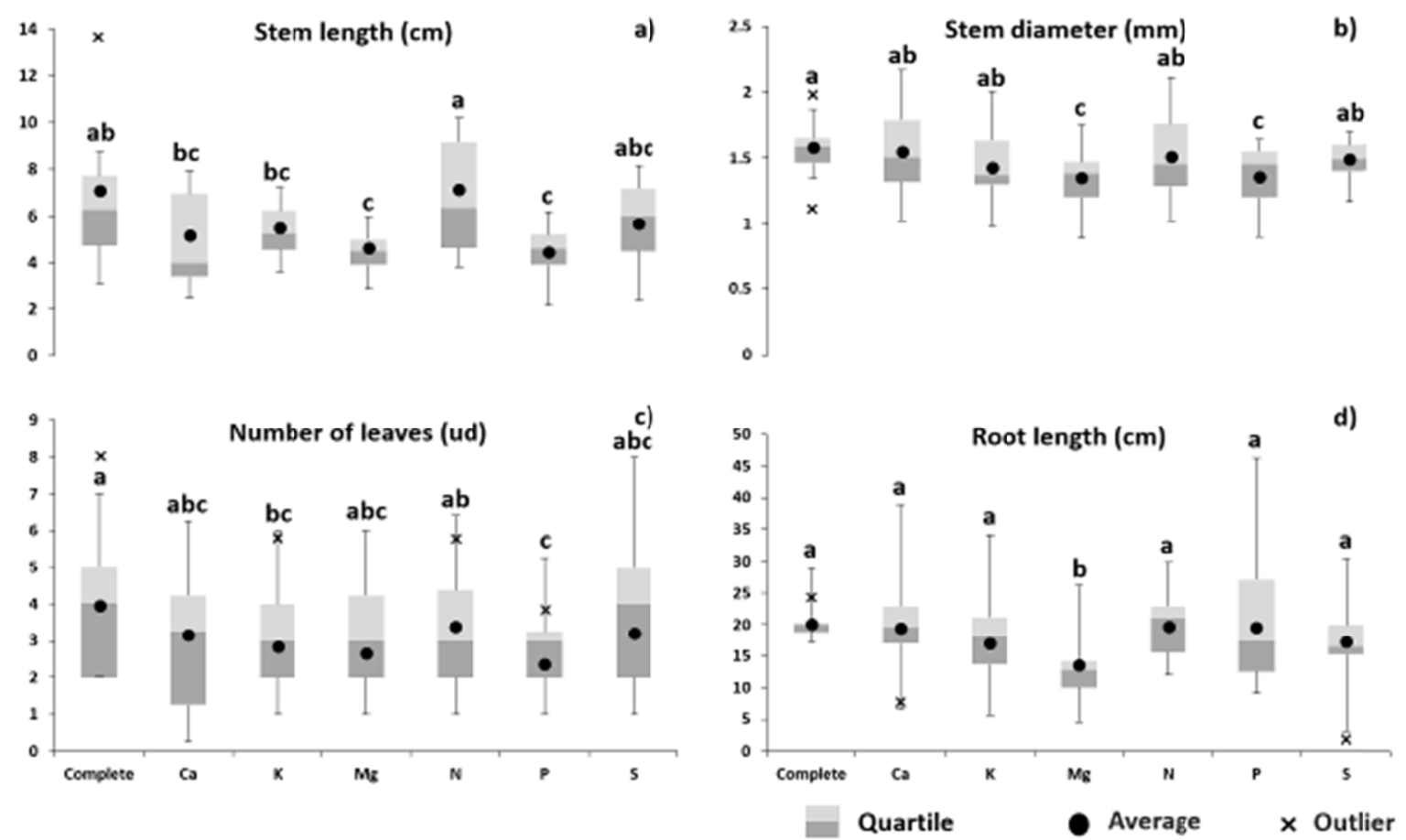

Figure 9. Effects of macronutrient omission on stem length $(\mathrm{cm})$, stem diameter $(\mathrm{mm})$, number of leaves and root length $(\mathrm{cm})$ of Eugenia dysenterica DC. seedlings grown in a hydroponic system with complete nutrient solution or without $\mathrm{Ca}, \mathrm{K}, \mathrm{Mg}, \mathrm{N}, \mathrm{P}$ or S. Data collected at 120 days after transplantation (DAT). *Letters above black spots compare omission treatments, according to the Tukey test ( $5 \%$ probability)

The highest mean stem diameter was observed in the treatment with complete nutrient solution $(1.58 \mathrm{~mm}$ mean stem diameter). Therefore, the omission of macronutrients affected the development of this structure. Similar to stem length, the lack of $\mathrm{Mg}$ and $\mathrm{P}$ ions limited stem development, and stems with a mean diameter of 1.35 and $1.36 \mathrm{~mm}$, respectively, were observed in the absence of these ions (Figure 9b). The $\mathrm{P}$ omission treatment also affected leaf development. At 120 DAT, plants subjected to this treatment showed a mean of 2.4 leaf units, whereas plants grown in complete nutrient solution showed a mean of 3.5 leaves in this period (Figure 9c). Following the same effect pattern, Mg omission inhibited root growth. At 120 DAT, the mean root length was $13.5 \mathrm{~cm}$ in plants subjected to this treatment, and the mean root length was $20.12 \mathrm{~cm}$ in plants grown in complete nutrient solution (Figure 9d).

The values of nutrients that had accumulated in the shoots of plants grown in complete nutrient solution were arranged in the following decreasing order: $\mathrm{Ca}>\mathrm{N}>\mathrm{K}>\mathrm{S}>\mathrm{Mg}>\mathrm{P}$, and the contents of this macronutrient accumulated in the roots of plants grown in complete nutrient solution were arranged in the following decreasing order: $\mathrm{N}>\mathrm{Ca}>\mathrm{K}>\mathrm{P}>\mathrm{Mg}>\mathrm{S}$.

\section{Discussion}

This study reports, for the first time, that several visual characteristics may be used to detect macronutrient deficiencies in E. dysenterica seedlings. Purple leaves, for example, may indicate low P availability. Flavonoid accumulation in leaf tissues, especially red/purple anthocyanins, is used as an indicator of changes in plant metabolism due to nutrient deficiency (Stewart et al., 2001). Studies have shown that P deficiency may stimulate 
secondary metabolism pathways related to the synthesis of bioactive compounds, such as essential oils and flavonoids (e.g., Jia et al., 2015; Valentinuzzi et al., 2015). Our data indicate that $E$. dysenterica plants also react to $\mathrm{P}$ omission by accumulating anthocyanins in their leaves. According to Pourcel et al. (2013), anthocyanins are key regulators of stress responses and plant development.

The presence of chlorosis or necrosis, which generally manifested as leaf spots or points, was the most common nutrient deficiency symptom in E. dysenterica seedlings. Chlorosis may be explained by two causal factors. First, under deficiency, nutrients that are already allocated to leaves are transported to other plant parts, and these nutrients are described as phloem-mobile. In such cases, chlorosis usually starts in younger leaves (Uchida, 2000). A second reason for chlorosis may be the low nutrient concentrations, which are unable to meet the leaf nutrient demands for growth because the quantity already allocated to leaves is insufficient. In such cases, chlorosis is particularly detected in younger leaves, which are deficient in phloem-immobile or poorly mobile nutrients. The development of necrosis may have merely represented a worsening of the chlorosis symptom, as occurs under $\mathrm{N}$ deficiency, although necrosis may be caused by the accumulation of basic amino acids (ornithine, citrulline and arginine) in other cases. These amino acids are decarboxylated, thereby increasing the concentration of putrescine (Ruiz \& Moyano, 2017; Epstein \& Bloom, 2006), a nitrogenous compound that is toxic to plants and responsible, for example, for the necrotic spots that appear on K-deficient leaves (e.g., Costa et al., 2017; Silva et al., 2017a).

Although studies suggest that E. dysenterica plants are highly adapted to soils with medium or low (Naves et al., 2002) fertility, our results confirmed the hypothesis that seedling growth of this species may be affected by the unavailability of specific nutrients. This effect is unsurprising because the lack of nutrients, either macronutrients, significantly alters nutrient uptake and transport in plant cells, primarily affecting proteins, which play a key role in deficiency-compensation responses (Nouri et al., 2016). However, our results showed that growth characteristics in E. dysenterica plants are primarily affected by limitations in the macronutrients $\mathrm{Mg}$ and $\mathrm{P}$. After $\mathrm{K}, \mathrm{Mg}$ is the second most abundant cation in plant cells. Many physiological processes, such as enzymatic activities and ribosomal subunit aggregation, depend on Mg (Gerendás \& Führs, 2013). In plants, Mg is the central atom of chlorophyll molecules. More than 300 enzymes are Mg-dependent, and changes in the concentration of Mg significantly affect the membrane potential. Kobayashi and Tanoi (2015) reported that starch accumulation and the development of chlorosis associated with reactive oxygen species generation occur in young and mature leaves under Mg deficiency. These problems may further affect photosynthesis and lead to a decrease in biomass. Sugar often accumulates in leaves under Mg deficiency because this nutrient is involved in carbohydrate transport from source to sink organs (Farhat et al., 2016). In turn, Peng et al. (2015) demonstrated that the levels of the photosynthesis-related enzymes ribulose-1,5-bisphosphate carboxylase/oxygenase $(\mathrm{RuBisCO}), \mathrm{RuBisCO}$ activase and ferredoxin-NADP $(+)$ reductase significantly decline under $\mathrm{Mg}$ deficiency.

E. dysenterica seedling growth was affected by the lack of $\mathrm{P}$, most likely because, under this condition, plants experience drastic cellular changes in metabolism, physiology, hormonal balance and gene expression (Ha \& Tran, 2014) because this is an essential nutrient involved in several fundamental biochemical processes, such as lipid metabolism and nucleic acid and cell membrane biosynthesis.

$\mathrm{N}, \mathrm{P}, \mathrm{K}, \mathrm{Ca}, \mathrm{Mg}, \mathrm{S}, \mathrm{B}, \mathrm{Cu}, \mathrm{Zn}$ and Mo differentially accumulated in E. dysenterica plant shoots, most likely due to competition or inhibition effects between nutrients because the presence of one element may affect plant uptake of another due to competition for the same absorption site (Epstein \& Bloom, 2006). Several shoot and root nutrient concentrations were higher in plants subjected to omission treatments than in plants grown in complete nutrient solutions, indicating an actual metabolic adjustment of E. dysenterica plants to adapt to and survive the stress caused by nutrient deficiency. According to Kulcheski et al. (2015), plants develop physiological and even molecular adaptive responses to cope with the lack of a nutrient, increasing the uptake of a specific ion in the absence of another. Knowledge concerning these adaptation mechanisms may lead to the development of important tools for plant improvement. Recent studies have shown, for example, the involvement of noncoding microRNAs in stress responses, including nutritional stress (Kulcheski et al., 2015; Jeong \& Green et al., 2013).

Plants that were grown in complete nutrient solution accumulated higher concentrations of $\mathrm{Ca}$ and $\mathrm{N}$ in shoots and roots. These nutrients are highly demanded by perennial and deciduous tree species, such as E. dysenterica. Aerts and Chapin (2000) showed that deciduous perennial species store more $\mathrm{N}$ in leaves than perennial evergreen, herbaceous or grass species, whereas Martre et al. (2003) modelled $\mathrm{N}$ accumulation and protein composition in wheat plants and generated key indicators showing that plant $\mathrm{N}$ accumulation is primarily regulated by the source. Our data corroborate these findings because plants grown in complete nutrient solution had higher values of the variables mean number of leaves and root length. Because leaf carbon accumulation is 
linearly related to leaf $\mathrm{N}$ content (Evans, 1989), plants in the initial growth stage, such as those evaluated in this study, must demand high $\mathrm{N}$ amounts to regulate carbon metabolism and amino acid and protein synthesis (Kulcheski et al., 2015). In a previous study, Bessa et al. (2016) found, at 180 DAT, that $E$. dysenterica seedlings demanded a high N and Ca supply. Anacardium othonianum Rizz., another fruit tree species native to the Cerrado, also showed an increase in $\mathrm{N}$ and $\mathrm{Ca}$ accumulation relative to other nutrients at 180 DAT (Bessa et al., 2013). In this study, Ca was essential for seedling growth. According to Tang et al. (2017), this element usually accounts for 0.1 to $5 \%$ of plant shoot dry matter. Although this element is abundant in nature, its deficiency occurs in rapidly growing tissues because it is an essential component of cell walls and of other cellular structures (Yamamoto et al., 2011).

\section{Conclusion}

Limitations of the macronutrients $\mathrm{Mg}$ and $\mathrm{P}$ are weakly tolerated by $E$. dysenterica seedlings. Therefore, farmers growing seedlings of this fruit tree should supply these nutrients. Chlorosis and necrosis symptoms are commonly observed in plants of this species under macronutrient deficiency and therefore can be used by seedling growers as signs of inaccessibility to nutrients. Plants grown in complete nutrient solution accumulated the highest shoot and root contents of the macronutrients $\mathrm{Ca}$ and $\mathrm{N}$, thus demonstrating the importance of the availability of these nutrients in the initial stages of seedling development in this species for the production of healthy plants, representing a strategy to maintain higher numbers of this fruit tree in the Cerrado biome.

\section{References}

Aerts, R., \& Chapin, F. S. (2000). The mineral nutrition of wild plants revisited: A re-evaluation of processes and patterns (p. 67). https://doi.org/10.1016/S0065-2504(08)60016-1

Almeida, S. P. (1998). Frutas nativas do cerrado: Caracterização físico-química e fonte potencial de nutrientes. In S. M. Sano, \& S. P. Almeida (Eds.), Cerrado: Ambiente e flora (pp. 247-285). Planaltina: Embrapa-CPAC.

Bessa, L. A., Moreira, M. A., Silva, F. G., Mota, C. S., \& Vitorino, L. C. (2016). Growth, nutrient concentration and principal component analysis of Cagaita (Eugenia dysenterica DC.) seedlings grown in nutrient solution. Australian Journal Crop Science, 10, 425-432. https://doi.org/10.21475/ajcs.2016.10.03.p7477

Bessa, L. A., Silva, F. G., Moreira, M. A., Teodoro, J. P. R., \& Soares, F. A. L. (2013). Characterization of nutrient deficiency in Hancornia speciosa Gomes seedlings by omitting micronutrients from the nutrient solution. Revista Brasileira de Fruticultura, 35, 616-624. https://doi.org/10.1590/S0100-29452013000 200034

Camilo, Y. M. V., Souza, E. R. B., Vera, R., \& Naves, R. V. (2013). Fenologia, produção e precocidade de plantas de Eugenia dysenterica visando melhoramento genético. Revista de Ciências Agrárias, 36, 192-198.

Coelho, G. L. N., Carvalho, L. M. T., \& Gomide, L. R. (2016). Modelagem preditiva de distribuição de espécies pioneiras no Estado de Minas Gerais. Pesquisa Agropecuária Brasileira, 51, 207-214. https://doi.org/ $10.1590 / \mathrm{S} 0100-204 \mathrm{X} 2016000300002$

Coruzzi, G., \& Bush, D. R. (2001). Nitrogen and carbon nutrient and metabolite signaling in plants. Plant Physiology, 125, 61-64. https://doi.org/10.1104/pp.125.1.61

Costa, L. C., Carmona, M. V., Cecílio Filho, A. B., \& Nascimento, C. S. (2017). Symptoms of deficiencies macronutrients in watermelon. Comunicata Scientiae, 8, 80-92. https://doi.org/10.14295/cs.v8i1.1477

Donado-Pestana, C. M., Moura, M. H. C., Araujo, R. L., Santiago, G. L., Barros, H. R. M., \& Genovese, M. I. (2018). Polyphenols from Brazilian native Myrtaceae fruits and their potential health benefits against obesity and its associated complications. Current Opinion in Food Science, 19, 42-49. https://doi.org/ 10.1016/j.cofs.2018.01.001

Donado-Pestana, C. M., Santos-Donado, P. R., Belchior, L. D. D. T., \& Genovese, W. T. F. M. I. (2018). Cagaita fruit (Eugenia dysenterica DC.) and obesity: Role of polyphenols on already established obesity. Food Research International, 103, 40-47. https://doi.org/10.1016/j.foodres.2017.10.011

Epstein, E., \& Bloom, A. J. (2006). Nutrição mineral de plantas: Princípios e perspectivas (p. 403). Londrina: Editora Planta.

Escobar-Fernandez, R., Gerreiro, M., Benlloch, M., \& Benlloch-González. (2016). Symptoms of nutrient deficiencies in young olive trees and leaf nutrient concentration at which such symptoms appear. Scientia Horticulture, 209, 279-285. https://doi.org/10.1016/j.scienta.2016.07.002 
Evans, J. R. (1989). Photosynthesis and nitrogen relationships in leaves of $\mathrm{C}_{3}$, plants. Oecologia, 78, 9-19. https://doi.org/10.1007/BF00377192

Farhat, N., Elkhouni, A., Zorrig, W., Smaoui, A., Abdelly, C., \& Rabhi, M. (2016). Effects of magnesium deficiency on photosynthesis and carbohydrate partitioning. Acta Physiology Plantarum, 38, 145. https://doi.org/10.1007/s11738-016-2165-z

Gerendás, J., \& Führs H. (2013). The significance of magnesium for crop quality. Plant and Soil, 368, 101-128. https://doi.org/10.1007/s11104-012-1555-2

Guo, W., Nazim, H., Liang, Z., \& Yang, D. (2016). Magnesium deficiency in plants: An urgent problem. Australian Journal of Crop Sience, 4, 83-91. https://doi.org/10.1016/j.cj.2015.11.003

Ha, S., \& Tran, L. S. (2014). Understanding plant responses to phosphorus starvation for improvement of plant tolerance to phosphorus deficiency by biotechnological approaches. Critical Reviews Biotechnology, 34, 16-30. https://doi.org/10.3109/07388551.2013.783549

Hafsi, C., Debez, A., \& Abdelly, C. (2014). Potassium deficiency in plants: Effects and signaling cascades, 36, 1055-1070. https://doi.org/10.1007/s11738-014-1491-2

Hoagland, D. R., \& Arnon, D. I. (1950). The water culture methods for growing plants without soil. California Agriculture Experiment Station: Berkeley, CA, USA.

Jeong, D. H., \& Green, P. J. (2013). The role of rice microRNAs in abiotic stress responses. Journal Plant Biology, 5, 187-197. https://doi.org/10.1007/s12374-013-0213-4

Jia, H., Wang, J., Yang, Y., Liu, G., Bao, Y., \& Cui, H. (2015). Changes in flavonol content and transcript levels of genes in the flavonoid pathway in tobacco under phosphorus deficiency. Plant Growth Regulation, 76, 225-231. https://doi.org/10.1007/s10725-014-9990-0

Koboyashi, N. I., \& Tanoi, K. (2015). Critical issues in the study of magnesium transport systems and magnesium deficiency symptoms in plants. International Journal of Molecular Sciences, 16, 23076-23093. https://doi.org/10.3390/ijms160923076

Kulcheski, F. R., Côrrea, R., Gomes, I. A., Lima, J. C., \& Margis, L. R. (2015). NPK macronutrients and microRNA homeostasis. Frontiers in Plant Science, 6, 1-18. https://doi.org/10.3389/fpls.2015.00451

Malavolta, E. (1997). Avaliação do estado nutricional das plantas princípios e aplicações (2nd ed., p. 319). Piracicaba: Associação Brasileira para Pesquisa da Potássio e do Fosfato.

Manuel, J. T., Alejandro, C. A, Angel, L., Aurora, G., \& Emilio, F. (2018). Roles of molybdenum in plants and improvement of its acquisition and use efficiency. Plant micronutrient use efficiency (pp. 137-159). Academic Press. https://doi.org/10.1016/B978-0-12-812104-7.00009-5

Marinho, D. G., Alviano, D. S., Matheus, M. E., Alviano, C. S., \& Fernandes, P. D. (2011). The latex obtained from Hancornia speciosa Gomes possesses anti-inflammatory activity. Journal Ethnopharmacology, 135, 530-537. https://doi.org/10.1016/j.jep.2011.03.059

Marschner, H. (2012). Mineral Nutrition of Higher Plants (3rd ed.). Academic Press, London.

Martre, P., Porter, J. R., Jamieson, P. D., \& Triboi, E. (2003). Modelling grain nitrogen accumulation and protein composition to understand the sink/source regulations of nitrogen remobilization for wheat. Plant Physiology, 133, 1959-1967. https://doi.org/10.1104/pp.103.030585

Moraes, T. M., Rodrigues, C. M., Kushima, H., Bauab, T. M., Villegas, W., Pellizzon, C. H., ... Hiruma-Lima, C. A. (2008). Hancornia speciosa: Indications of gastroprotective, healing and anti-Helicobacter pylori actions. Journal Ethnopharmacol, 120, 161-168. https://doi.org/10.1016/j.jep.2008.08.001

Munson, R. D. (2018). Soil fertility, fertilizers, and plant nutrition. In V. J. Kilmer (Ed.), Handbook of Soils and Climate in Agriculture (p. 26). https://doi.org/10.1201/9781351073073-7

Naves, R. V., Borges, J. D., \& Chaves, L. J. (2002). A cagaiteira. Revista Brasileira de Fruticultura, 24(2), 289-596. https://doi.org/10.1590/S0100-29452002000200001

Nouri, M. Z., Ghaffari, M. R., Sobhanian, H., \& Hajirezaei, M. R. (2016). Proteomics approach for identification of nutrient deficiency related proteins in crop plants. In G. Salekdeh (Ed.), Agricultural Proteomics (Volume 2). Springer, Cham. https://doi.org/10.1007/978-3-319-43278-6_8 
Ogunwande, I. A., Olawore, N. O., Ekundayo, O., Walker, T. M., Schmidt, J. M., \& Setzer, W. N. (2005). Characterization of the biological potential of the essential oils from five species of medicinal plants. Intertatioal Journal Aromatherapy, 15, 147-152. https://doi.org/10.1016/j.ijat.2005.07.004

Peng, H. Y., Qi, Y. P., Lee, J., Yang, L. T., Guo, P., Jiang, H. X., \& Chen, L. S. (2015). Proteomic analysis of Citrus sinensis roots and leaves in response to long-term magnesium-deficiency. BMC Genomics, 31, 16-253. https://doi.org/10.1186/s12864-015-1462-z

Pourcel, L., Irani, N. G., Koo, A. J. K., Bohorquez-Restrepo, A., Howe, G. A., \& Grotewold, E. (2013). A chemical complementation approach reveals genes and interactions of flavonoids with other pathways. Plant Journal, 74, 383-397. https://doi.org/10.1111/tpj.12129

R. Core Team. (2018). R: A language and environmental for statistical computing. R Foundation for Statistical Computing, Viena, Austria.

Resende, C. F. A, Fernandes, E. P., Silva, M. F., \& Leandro, W. M. (2010). Crescimento e acúmulo de nutrientes em mudas cítricas cultivadas em ambiente protegido. Bioscience Journal, 26, 367-375.

Ribeiro, J. F., Oliveira, M. C., Felfili, J. M., Aquino, F. G., \& Gulias, A. P. S. M. (2008). Usos múltiplos da biodiversidade no bioma Cerrado: Estratégia sustentável para a sociedade, o agronegócio e os recursos naturais. In F. G. Faleiro, \& A. L. Farias Neto (Eds.), Savanas: Desafios e estratégias para o equilibrio entre sociedade, agronegócio e recursos naturais (pp. 337-360). Brasília: Embrapa Informação Tecnológica.

Ruiz, R. S., \& Moyano, S. A. (2017). El problema de "Palo negro" en vides y su relación con altos niveles de putrescina y bajo contenido de potasio. Agricultura Tecnica, 54, 87-94.

Santos, P. R. G., Cardoso., L. M., Bedetti, S. F., Hamacek, F. R., Moreira, A. V. B., Martino, H. S. D., \& Pinheiro-Sant Ana, H. M. (2012). Geleia de cagaita (Eugenia dysenterica DC.): desenvolvimento, caracterização microbiológica, sensorial, química e estudo da estabilidade. Revista Instituto Adolfo Lutz, 71, 281-90.

Santos, S. C., Ribeiro, J. P., Guimarães, D. O., Silva, M. O., Ferri, P. H., Garcia, A. C. F., ... Paula, J. R. (2004). Antifungal activity of Eugenia uniflora L. fractions against Paracoccidiodes brasiliensis (Splendore) Almeida. Revista Brasileira de Plantas Medicinais, 7, 30-33.

Schmidt, S. B., Jensen, P. E., \& Husted, S. (2016). Manganese deficiency in plants: The impact on photosystem II. Trends Plant Science, 21, 622-632. https://doi.org/10.1016/j.tplants.2016.03.001

Shear, C. B., \& Faust, M. (1980). Nutritional ranges in deciduous tree fruits and nuts. Horticultural Reviews, 2, 142-163. https://doi.org/10.1002/9781118060759.ch3

Silva, A. Z., Anderson, F. W., Nowaki, R. H., Filho, A. B. C., \& Mendoza-Cortez, J. W. (2017a). Síntomas de deficiencia de macronutrientes en pimiento (Capsicum annuиm L.). Agrociencia Uruguay, 21, 31-43.

Silva, G. C., Braga, F. C., Lima, M. P., Pesquero, J. L., Lemos, V. S., \& Cortes, S. F. (2011). Hancornia speciosa Gomes induces hypotensive effect through inhibition of ACE and increase on NO. Journal Ethnopharmacol, 137, 709-713. https://doi.org/10.1016/j.jep.2011.06.031

Silva, L. A., Sales, J. F., Santos, H. O., Martins, J. M., Costa, V. H., \& Silva, F. G. (2017b). Physiological performance of cagaita seeds (Eugenia dysenterica DC.) Subjected to drying. Semina: Ciências Agrárias, 38, 19-34. https://doi.org/10.5433/1679-0359.2017v38n1p19

Sousa, E. R. B., Camilo, Y. M. V., \& Vera, R. (2018). Cagaita-Eugenia dysenterica. Exotic Fruits, 77-83. https://doi.org/10.1016/B978-0-12-803138-4.00011-3

Stewart, A. J., Chapman, W., Jenkins, G. I., Graham, I., Martin, T., \& Crozier, A. (2002). The effect of nitrogen and phosphorus deficiency on flavonol accumulation in plant tissues. Plant Cell Environmental, 24, 1189-1197. https://doi.org/10.1046/j.1365-3040.2001.00768.x

Tang, R., \& Luan, S. (2017). Regulation of calcium and magnesium homeostasis in plants: from transporters to signaling network. Current Opinon Plant Biology, 39, 97-105. https://doi.org/10.1016/j.pbi.2017.06.009

Telles, M. P. C., Diniz-Filho, J. A. F., Coelho, A. S. G., \& Chaves, L. J. (2001b). Autocorrelação espacial das frequências alélicas em subpopulações de cagaiteira (Eugenia dysenterica DC, Mytaceae) no Sudeste de Goiás. Revista Brasileira de Botânica, 24, 145-154. https://doi.org/10.1590/S0100-84042001000200003 
Uchida, R. (2000). Essential nutrients for plant growth: nutrient functions and deficiency symptoms. In J. A. Silva, \& R. Uchida (Eds.), Plant nutrient management in Hawaii's soils, approaches for tropical and subtropical agriculture. College of Tropical Agriculture and Human Resources, University of Hawaii at Manoa.

Valentinuzzi, F., Mason, M., Scampicchio, A., Cesco, S., \& Mimmo, T. (2015). Enhancement of the bioactive compound content in strawberry fruits grown under iron and phosphorus deficiency. Journal of the Science Food Agricultural, 15, 2088-94. https://doi.org/10.1002/jsfa.6924

Yamamoto, E. L. M., Ferreira, R. M. A., Fernandes, P. L. O., Albuquerque, L. B., \& Alves, E. O. (2011). Função do cálcio na degradação da parede celular vegetal de frutos. Revista Verde, 6, 49-55.

Zucchi, M. I., Pinheiro, J. B., Chaves, L. J., Coelho, A. S. G., Couto, M. A., Morais, L. K., \& Vencovsky, R. (2005). Genetic structure and gene flow of Eugenia dysenterica natural populations. Pesquisa Agropecuária Brasileira, 40, 975-980. https://doi.org/10.1590/S0100-204X2005001000005

\section{Copyrights}

Copyright for this article is retained by the author(s), with first publication rights granted to the journal.

This is an open-access article distributed under the terms and conditions of the Creative Commons Attribution license (http://creativecommons.org/licenses/by/4.0/). 